\title{
Impact of surgery and chemotherapy on cellular immunity in pancreatic carcinoma patients in view of an integration of standard cancer treatment with immunotherapy
}

\author{
GRAZIELLA BELLONE ${ }^{1}$, ANNA NOVARINO ${ }^{2}$, BARBARA VIZIO ${ }^{1}$, GABRIELE BRONDINO $^{1}$, \\ ALFREDO ADDEO $^{3}$, ADRIANA PRATI ${ }^{1}$, ALICE GIACOBINO ${ }^{2}$, DONATA CAMPRA ${ }^{4}$, \\ GIAN RUGGERO FRONDA ${ }^{4}$ and LIBERO CIUFFREDA ${ }^{2}$ \\ ${ }^{1}$ Department of Clinical Physiopathology, University of Turin; ${ }^{2}$ Department of Clinical Oncology, \\ San Giovanni Battista (Molinette) Hospital; ${ }^{3}$ Clinical Oncology, San Giovanni Bosco Hospital, ASLTO2; \\ ${ }^{4}$ Department of Surgery, San Giovanni Battista (Molinette) Hospital, Turin, Italy
}

Received December 9, 2008; Accepted February 5, 2009

DOI: 10.3892/ijo_00000301

\begin{abstract}
As surgery and chemotherapy may act as adjuvants providing antitumor immunity benefits, we ran phenotypical and functional immunomonitoring in patients with resectable pancreatic adenocarcinoma and advanced metastatic disease receiving combined treatment (cisplatin, gemcitabine, 5-FU). Blood was taken before/one month after resection; before/ during chemotherapy. Controls were age- and gender-matched. Circulating lymphocyte, myeloid and plasmacytoid dendritic cell (MDC and PDC) subsets were examined by flow cytometry; functional activity by mixed lymphocyte reaction (MLR) for DC allostimulation, through 4-h ${ }^{51} \mathrm{Cr}$-release assay for Natural Killer (NK) and lymphokine-activated-killer (LAK) cell cytotoxicity; ELISA for spontaneous/activated cytokine release by PBMC and T cells. Significant differences occurred in several parameters between pretreatment patient and control values: fewer $\mathrm{CD}^{+}$cells and increased apoptosisprone $\mathrm{CD}^{+} / \mathrm{CD} 5^{+}$lymphocytes, higher frequency of MDC, reduced allostimulatory activity by ex vivo-generated DC, depressed LAK activity, elevated IL-10 and IL-12p40 production; impaired IL-12p70 and IFN- $\gamma$ production by stimulated PBMC and T cells. Only IL-12p70 level was correlated with survival. One month after radical, but not palliative surgery, the percentage of T-lymphocytes coexpressing CD3/CD95 decreased significantly, the stimulatory capacity of DC increased, and LPS-induced IL12 p70 release by PBMC rose concomitantly with the anti-CD3 stimulated-IFN- $\gamma$ production by $\mathrm{T}$ cells. In patients with locally advanced or metastatic disease, one and/or two
\end{abstract}

Correspondence to: Dr Graziella Bellone, Department of Clinical Physiopathology, Via Genova 3, 10126 Torino, Italy

E-mail: graziella.bellone@unito.it

Key words: pancreatic carcinoma, tumor immunity, chemotherapy, immunotherapy, surgery combined drug cycles increased percentage of $\mathrm{CD}^{+}$cells and LAK cell cytotoxicity and decreased PDC frequency and spontaneous/LPS-stimulated IL-10 by PBMC. Results suggest immunological changes induced by surgical resection/ combined chemotherapy indicate specific precisely-timed windows of opportunity for introducing immunotherapy in pancreatic cancer, possibly improving survival in this highly lethal disease.

\section{Introduction}

The typical late presentation of pancreatic carcinoma and its clinicopathological behaviour give the disease a poor prognosis with little chance of a cure under present management (1). Curative resection remains the most important factor determining outcome for resectable tumors. However, the resection rate for pancreatic carcinoma is only $10 \%$ and the overall five-year survival rate after resection is still only 10 to $20 \%$ (2). The majority of the patients have either locally advanced disease that is not amenable to surgical resection, or metastatic disease that is frequently refractory to standard forms of chemotherapy (3).

In the last decade, the availability of several active new drugs has improved the efficacy of combination regimens and substantially increased the response rates of several refractory tumors $(4,5)$. However, recent randomized trials testing combined chemotherapies in pancreatic cancer indicated the regimen to be feasible, but without any major advantage over single agent treatment (6).

At the molecular level, it is generally believed that the anticancer properties of chemotherapic agents derive from activation of apoptosis pathways and/or the arrest of celldivision (7). However, several lines of evidence indicate that antitumor drugs might mediate their effects by other modes of action. In experimental and in vitro models, some drugs used to treat pancreatic carcinoma, such as cisplatin, gemcitabine and 5-FU, have in addition to their cell-autonomous antitumor effects, demonstrated indirect activity on host immune system, by increasing the cytotoxic response and/or enhancing cancer cells' sensitivity to the killer action (8-11). 
Active tumor-specific immune responses in pancreatic cancer patients have been clearly established (12). However, the host's defence against the tumor does not appear to be effectively induced, suggesting the capacity of tumor cells either to hide from immune cells, by avoiding recognition, or to disable or eliminate immune cells.

Multiple lines of evidence indicate that the main escape strategies of tumor cells against cell-mediated killing are altered local interactions between cytotoxic $\mathrm{T}$ lymphocytes (CTL) and the tumor cells $(13,14)$, and the release of a variety of soluble molecules that depress $\mathrm{T}$ lymphocyte responses and dendritic cell (DC) activity. These latter include Transforming Growth Factor (TGF)- $B$ and Interleukin (IL)-10 (15). Other released molecules lead to the induction of apoptosis in activated CTL, such as the Fas ligand (16).

Pancreatic carcinoma cells have been shown to spontaneously secrete these cytokines in vivo, thus defending themselves against immune attack or down-regulate the host's immune system $(17,18)$. Moreover, systemically elevated serum levels of the potentially immunosupressive cytokines IL-10 and TGF- $\beta$, as well as T and DC subsets favouring tolerizing conditions, have also been reported in pancreatic carcinoma patients $(19,20)$.

Given the multiplicity of regulatory pathways that shut off tumor-specific immune responses, it is not surprising that most clinical trials testing active immunotherapy as a single intervention in patients with advanced pancreatic cancers have failed to demonstrate any bioactivity clinically (21).

Accumulating data suggest the benefits of rationally combining active immunotherapy with surgery and chemotherapy in a rational fashion (22-25). It is thus imperative to investigate the impact of the current therapeutic modalities on tumor immunity. The aim of the present pilot study was to examine the immunomodulating properties of potentially curative resection or chemotherapy in patients with pancreatic carcinoma.

\section{Materials and methods}

Patients. The study was conducted on 16 consecutive patients (12 men and 4 women) diagnosed with pancreatic carcinoma at the Department of Clinical Oncology, San Giovanni Battista (Molinette) Hospital, Turin, Italy, between March 2005 and September 2005. None had undergone anticancer treatment before entering the study. All participating patients were required to give informed consent before entering the study and the procedures followed were in accordance with the Helsinki Declaration. The median age of the patients was 65 years (range: 52 to 83 years). The tumors were classified according to the UICC Staging System (26) as follows: stage II, $\mathrm{n}=1$; III, $\mathrm{n}=1$; stage IVa, $\mathrm{n}=3$; stage IVb, $\mathrm{n}=11$, of which eight with hepatic metastases, one with lung and hepatic metastasis, and two with peritoneal metastasis. None of the patients had undergone radiotherapy. Nine patients underwent surgical tumor resection, four radical and five palliative. Two of these latter underwent gastroenteroanastomosis (in one case the disease was locally advanced; in the other peritoneal metastases were present). Three underwent resection with macroscopic residue (R2) and at surgery metastatic disease was detected (in two cases in the liver and in one in the interaortocaval lymph node). Seven patients did not undergo surgery as their tumor was non-resectable. Three did not start chemotherapy owing to early death from advanced disease or clinical deterioration. One patient died of coronary artery disease (CAD) three days after radical surgery; one had no need for medical treatment after radical surgery. Eleven patients underwent chemotherapy for locally advanced and/or metastatic disease. The planned combination chemotherapy consisted of cisplatin $\left(20 \mathrm{mg} / \mathrm{m}^{2}\right.$ delivered as a 30-min infusion in $250 \mathrm{ml}$ of normal saline, with adequate prehydration accompanied by adequate urinary output, on days $1,8,15,22$, 29 and 36), gemcitabine $\left(1000 \mathrm{mg} / \mathrm{m}^{2}\right.$ given as a $30-\mathrm{min}$ infusion in $250 \mathrm{ml}$ of normal saline on days 1, 8, 29 and 36) and 5-fluorouracil (FU) $\left(200 \mathrm{mg} / \mathrm{m}^{2}\right.$ supplied as continuous infusion on days 1-42) (27). Immunological parameters were measured on the day of admission (time 0 ) before surgery or chemotherapic treatment, and, in parallel to the evaluation of the clinical course, one month after surgery or after each 56-day cycle of therapy. All patients were observed until they died or dropped out, or until December 2007. Fifteen patients (94\%) died; 14 of these (87\%) died of the disease and $1(6 \%)$ died of other causes. At the end of December 2007, only one patient was still surviving, after radical surgery and 8 months of chemotherapy.

Cell isolation. Peripheral blood (PB) from patients was collected in heparinised tubes, before surgery or before the first chemotherapy cycle and subsequently after tumor resection or after each cycle. Blood from age and gendermatched hospital staff volunteers was collected in parallel as control. PB mononuclear cells (MC) were isolated by centrifugation over Ficoll-Hypaque density gradient. Lymphocyte (PBL) were obtained by depletion of plastic adherent monocytes.

Flow cytometry analysis. To determine lymphocyte subsets, PBL were used for single or two-color cell surface labeling using the following monoclonal antibodies (MoAb): FITCconjugated anti-CD3,-CD4,-CD8,-CD56,-CD19 and phycoerythrin (PE )-conjugated anti-CD95. Circulating myeloid and plasmacytoid (MDC and PDC) subsets were measured by three-color flow cytometry as described elsewhere (20). PBMC were stained with lineage MoAb cocktail (LIN), consisting in FITC-conjugated anti-CD3, -CD14, -CD16, -CD19, -CD20, -CD56 mixture; PerPC-labelled anti-HLA-DR and PE-labelled anti-CD11c- or anti-CD123. All MoAb and FITC-, PE- and PerCP-conjugated isotype control murine $\mathrm{MoAb}$ were obtained from BD Pharmingen (San Diego, CA). Cells were stained with $\mathrm{MoAb}$ at $4^{\circ} \mathrm{C}$ for $30 \mathrm{~min}$. After washing, labeled cells were analyzed using an EPICS IV (Beckman Coulter, Inc., Fullerton, CA) flow cytometer. MDC and PDC were defined as $\mathrm{LIN}^{-}\left(\mathrm{CD}^{-}, \mathrm{CD} 14^{-}, \mathrm{CD} 16^{-}\right.$,

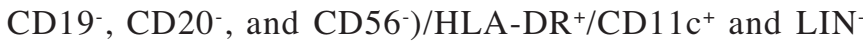
(CD3-, CD14-, CD16-, CD19-, CD20- and CD56-)/HLA-DR ${ }^{+} /$ $\mathrm{CD} 123^{+}$cells, respectively, as reported elsewhere in details (20). The incidence of each subset was expressed as a percentage of LIN- HLA-DR ${ }^{+}$PBMC. In addition, the MDC:PDC ratio was determined for each subject at the time of sampling. 
Generation of DC from adherent peripheral blood cells. Human monocytes were isolated from normal donors and patients PBMC by selection of cells adherent to cell-culturetreated plastic surfaces $\left(1 \times 10^{7} \mathrm{PBMC} / \mathrm{ml}, 2 \mathrm{~h}\right)$. DC were generated from adherent cells $\left(1 \times 10^{6}\right.$ cells $\left./ \mathrm{ml}\right)$ in 6 -well culture plates (Costar, Cambridge, MA, USA) in RPMI-1640 containing $10 \%$ heat-inactivated FCS and penicillin/ streptomycin (complete medium) supplemented with human recombinant GM-CSF $(100 \mathrm{ng} / \mathrm{ml})$ and $\mathrm{IL}-4(10 \mathrm{ng} / \mathrm{ml})$ (R\&D Systems, Minneapolis, MN).

Allogeneic $T$ cell proliferation assay. DC cells were used in primary mixed lymphocyte reaction (MLR) to stimulate allogeneic responder $\mathrm{T}$ cells isolated by negative immunomagnetic depletion of non-adherent PBMC from healthy volunteers using a monoclonal antibody mixture containing anti-CD14,-CD19,-CD20,-CD16 and -CD36 (BD Pharmingen) and MACS separation columns (Miltenyi Biotec, Bergisch Gladbach, Germany). Irradiated (30 Gy) DC from normal subjects or from the patients in the study were mixed with allogeneic $\mathrm{T}$ cells $\left(2 \times 10^{5} / 200 \mu \mathrm{l}\right)$ at a ratio of 1:20 in 96-well $\mathrm{U}$ bottom culture plates in complete medium. To determine DNA synthesis, cells were pulsed with $0.5 \mu \mathrm{Ci}$ of $\left[{ }^{3} \mathrm{H}\right]-\mathrm{TdR}(\mathrm{GBq} / \mathrm{mmol}$; PerkinElmer Life and Analytical Sciences, Waltham, MA, USA) for the last $5 \mathrm{~h}$ of a 5-day culture period. Cellular DNA was collected on glass fiber filters and $\left[{ }^{3} \mathrm{H}\right]-\mathrm{TdR}$ incorporation was measured in a $\mathrm{B}$ counter. Results are presented as a stimulation index (SI) value which was the ratio between the proliferative response (counts per minute, c.p.m.) of T cells in the presence and in the absence in the culture of DC from patients or from controls.

Cytokine assay. PBMC from patients and controls were treated with bacterial lipopolysaccharide (LPS, $1 \mu \mathrm{g} / \mathrm{ml}$ ) for $24 \mathrm{~h}$ to induce IL-10, IL-12p40 and IL-12p70 production while PBL were treated with plate-bound anti-CD3 MoAb $(1 \mu \mathrm{g} / \mathrm{ml})$ (Immunotech, Marseille, France) for $48 \mathrm{~h}$ to stimulate IFN- $\gamma$ release. The supernatants were harvested and IL-10, IL-12 total $\mathrm{p} 40, \mathrm{IL}-12 \mathrm{p} 70$ and IFN- $\gamma$ protein concentrations were determined with enzyme-linked immunosorbent assay (ELISA) using kits from R\&D (Minneapolis, MN) for IL-10 and IFN- $\gamma$ and from Pierce Endogen (Rockford, IL) for IL-12 total p40 and IL-12p70. The lower sensitivity thresholds were $<3.9 \mathrm{pg} / \mathrm{ml},<5 \mathrm{pg} / \mathrm{ml},<3 \mathrm{pg} / \mathrm{ml}$ and $<8 \mathrm{pg} / \mathrm{ml}$, respectively.

Cytotoxicity assays. Natural Killer (NK) cell activity was tested in the PBL population against the NK-sensitive human chronic myelogenous leukaemia cell line K562. To test Lymphokine Activated Killer (LAK) cell activity, PBMC were cultured for 7 days with $100 \mathrm{U} / \mathrm{ml}$ human recombinant Interleukin (IL)-2 (Novartis Vaccines \& Diagnostics, Inc., CA, USA). Lytic activity of these effectors were tested against the NK-resistant human Burkitt's lymphoma cell line Daudi. Briefly, effector PBL, freshly isolated or cultured with IL-2, were plated in $100 \mu \mathrm{l}$ aliquots $\left(2.5 \times 10^{6} \mathrm{cells} / \mathrm{ml}\right.$ in complete medium) in 96-well V-bottomed microtiter plates (Costar). Tumor targets were incubated with $100 \mu \mathrm{Ci}$ of sodium $\left[{ }^{51} \mathrm{Cr}\right]$ chromate (PerkinElmer) for $60 \mathrm{~min}$ at $37^{\circ} \mathrm{C}$ and washed twice to remove excess isotope. A quantity amounting to

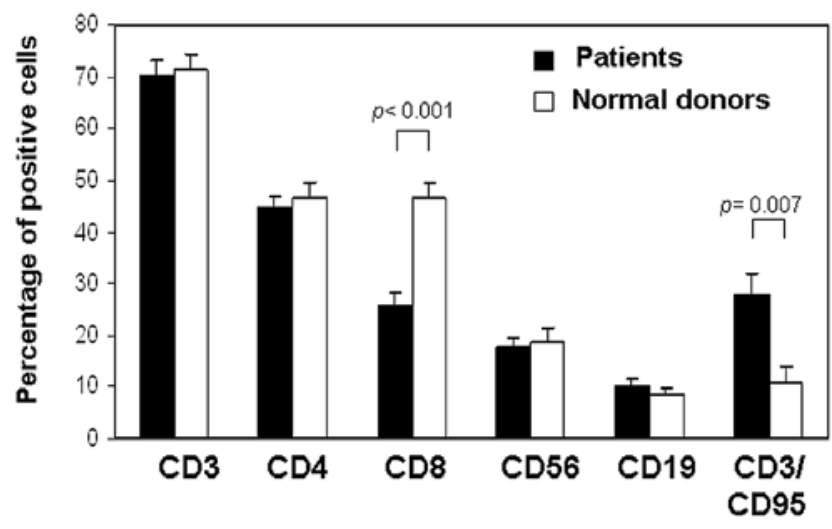

Figure 1. Histogram plots comparing the percentage of lymphocyte population identified phenotypically by flow cytometry in peripheral blood from pancreatic carcinoma patients $(n=16)$ and normal subjects $(n=16)$. No significant changes were seen in the proportion of $\mathrm{CD}^{+}, \mathrm{CD}^{+}, \mathrm{CD}^{2} 6^{+}, \mathrm{CD} 19^{+}$ cell subsets in the two groups. The proportion of $\mathrm{CD}^{+}$decreased and that of CD3/CD95 double staining positive lymphocytes significantly increased in patients vs. control. P, Mann-Whitney U test.

$5 \times 10^{3}$ cells/well was added to the effector cells, to assess an effector-to-target (E/T) ratio of 50:1. After $4 \mathrm{~h}$ incubation at $37^{\circ} \mathrm{C}$ in a $\mathrm{CO}_{2}$ incubator, $100 \mu \mathrm{l}$ of supernatant were removed from each well for isotope counting in a $\gamma$-counter (Packard, Downers Grove, IL, USA). Spontaneous and maximum release were estimated by incubating targets in medium alone or in medium plus $1 \mathrm{M}$ of $\mathrm{HCl}$, respectively. Spontaneous release did not exceed $15 \%$ of maximum release. In all cases, cultures were set up in triplicate and \% specific target cell lysis was calculated as follows: [(experimental release spontaneous release)/ (maximal release - spontaneous release)] x 100 .

Statistical analysis. Variables were compared by means of Student's t-test or a non-parametric test (Mann-Whitney) for intergroup comparisons. For matched pairs, Student's t-test or Wilcoxon's signed-rank test were applied. For survival analysis, patients were subdivided into quartiles and by median of parameters analyzed. Overall survival rates were analyzed using Kaplan-Meier curves and the related log-rank test. Differences were considered significant when $\mathrm{p}<0.05$. All of the statistical analyses were performed using the SPSS software package (13.0) for Windows (SPSS, Inc, Chicago, IL).

\section{Results}

Decreased percentage of $C D 8^{+}$lymphocytes and increased $C D 3^{+} / C D 95^{+}$lymphocytes in pancreatic carcinoma patients. To investigate the basal immune system status of patients, lymphocyte populations were analyzed for specific surface markers by flow cytometry. PBL from healthy donors were used as controls. Patients had significantly lower median lymphocyte counts $\left(1.8\right.$, range $\left.0.87-2.2 \times 10^{6} / \mathrm{ml}\right)$ than normal controls $\left(2.1\right.$, range $\left.1.1-3.8 \times 10^{6} / \mathrm{ml}\right)$. In addition, as shown in Fig. 1, no differences in frequency of $\mathrm{T}$ helper (h) $\mathrm{CD}^{+}, \mathrm{B}$ lymphocytes $\left(\mathrm{CD} 19^{+}\right)$or NK cells $\left(\mathrm{CD} 56^{+}\right)$among PBL were observed in patients versus (vs.) normal subjects. However, 

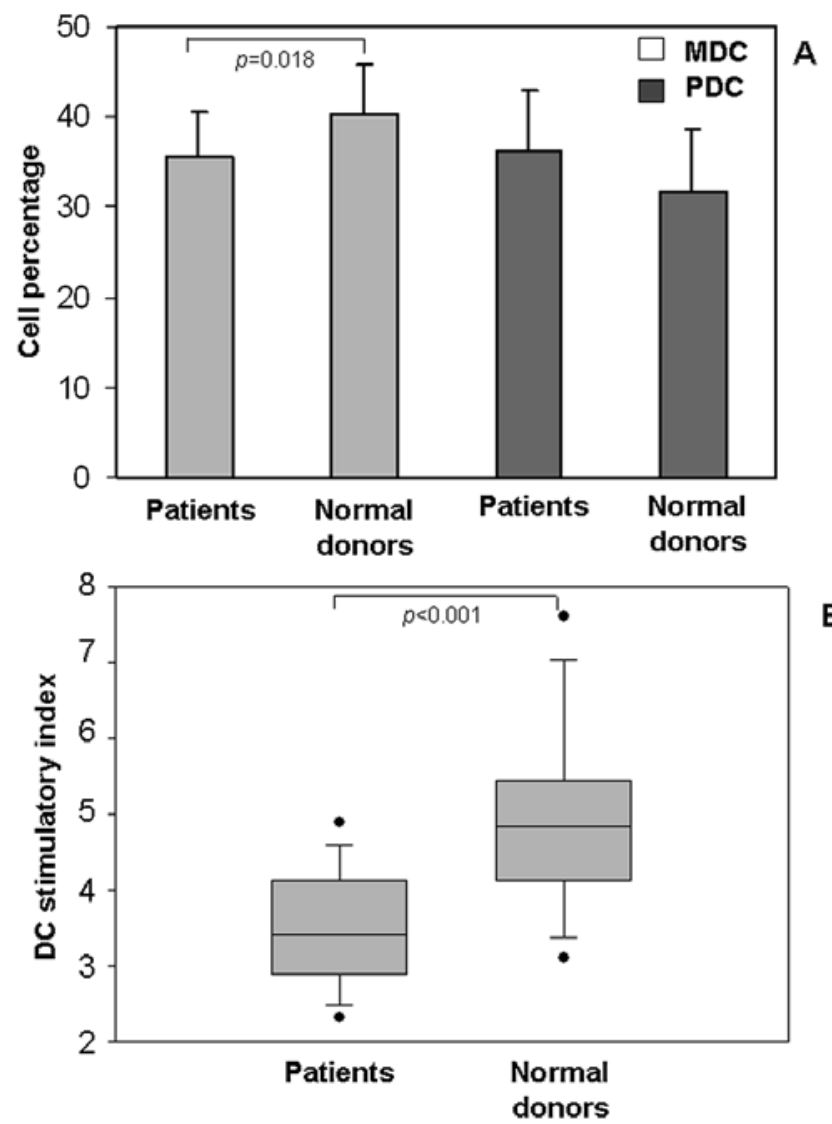

Figure 2. (A) The MDC subset is significantly depleted in patients with pancreatic carcinoma. The incidence of MDC $\left(\mathrm{CD} 11 \mathrm{c}^{+}, \mathrm{CD} 1233^{-}\right)$and $\mathrm{PDC}$ $\left(\mathrm{CD} 11 \mathrm{c}^{-}, \mathrm{CD} 123^{+}\right)$subsets are expressed as percentages of LIN- HLA-DR ${ }^{+}$ PBMC. Values are means \pm SD. Significant differences between patient groups and healthy donors are indicated. (B) Comparison of allostimulatory index from DC from pancreatic cancer patients before surgery and/or chemotherapy and controls. DC were generated by culturing PB adherent cells from patients and normal donors for 7 days in the presence of GM-CSF and IL-4. Cells were harvested, irradiated, and used to stimulate allogeneic $\mathrm{T}$ cells at a ratio of 1:20. T cells proliferation was determined using $\left[{ }^{3} \mathrm{H}\right]-$ TdR uptake after 5 days of culture. The stimulatory capacity of DC in patients with pancreatic cancer was significantly lower than that of controls $(\mathrm{p}<0.001)$. Data are expressed as the median (interquartile interval) of Stimulatory Index (SI). Statistical significance was determined using the Mann-Whitney U test.

the mean percentage of $\mathrm{CD}^{+}$cells was significantly lower (mean \pm SE, $24.4 \pm 2.8$ vs. $46.7 \pm 3, \mathrm{p}<0.001$ ) and that of a lymphocyte subset characterized by coexpression of CD3 and Fas (CD95) and was significantly higher $(27.8 \pm 4.1$ vs. $11 \pm 2.8$, $\mathrm{p}=0.007)$ in patients than in the normal control group.

Altered balance between MDC and PDC and impairement of allostimulatory activity of $D C$ generated ex vivo from pancreatic carcinoma patients. Two different subsets with distinct biological activities, MDC and PDC, have been defined on the basis of their distinct phenotypic characteristics, LIN $^{-}$HLA-DR ${ }^{+}$CD $11 c^{+}$and LIN- HLA-DR ${ }^{+}$CD $123^{+}$cells (28). Immunophenotyping of normal and cancer blood samples was performed by FACS analysis. The proportions of LIN- HLA$\mathrm{DR}^{+}$cells were comparable ranging from 0.61 to $4.9 \%$ for healthy individuals and from 0.59 to $5.3 \%$ for pancreatic carcinoma patients. The proportions of $\mathrm{LIN}^{-} \mathrm{HLA}-\mathrm{DR}{ }^{+} \mathrm{CD} 11 \mathrm{c}^{+}$ (MDC) or $\mathrm{LIN}^{-} \mathrm{HLA}_{-\mathrm{DR}}^{+} \mathrm{CD} 123^{+}$(PDC) subsets were
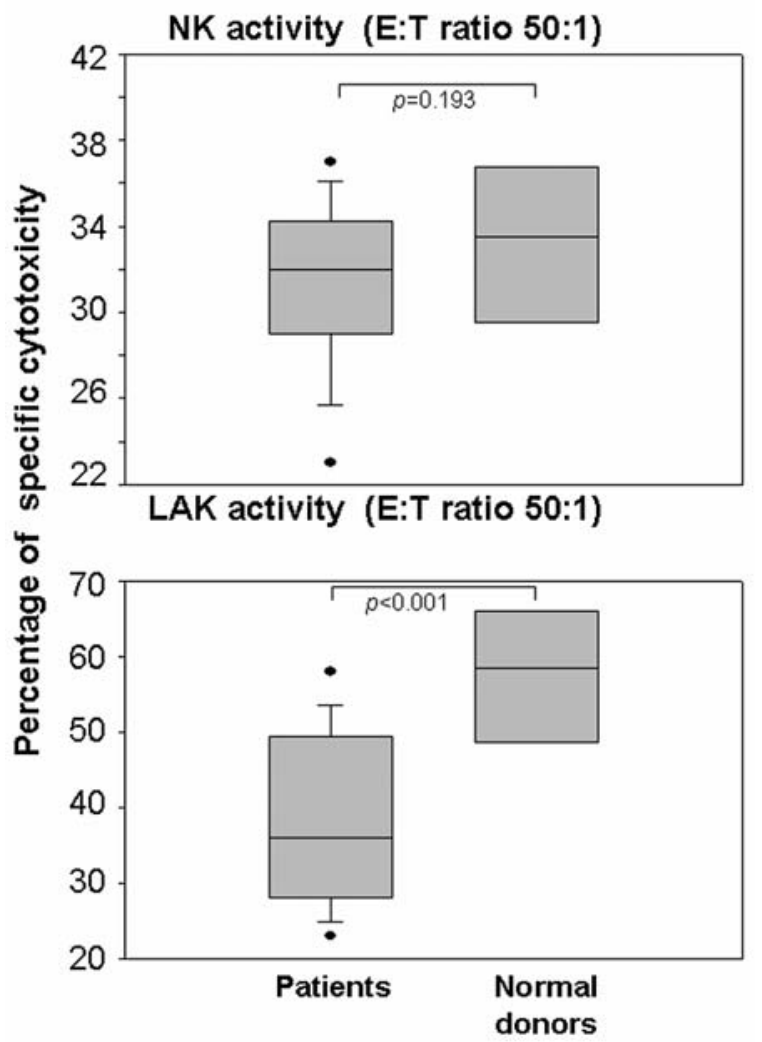

Figure 3. Baseline NK and IL-2-induced LAK activity. NK and LAK cells from pancreatic carcinoma patients and normal controls were tested in a 4-h ${ }^{51} \mathrm{Cr}$-release assay respectively against K562 and against the Burkitt's lymphoma cell line Daudi tumor targets, at an effector-to-target cell ratio of 50:1. Box plots of percentage of specific cytotoxicity against sensitive tumor targets are shown. Horizontal lines indicate 10th, 25th, 50th (median), 75th, and 90th percentiles. Values above the 90th and below the 10th percentiles are plotted as points. Statistical significance was determined using the Mann-Whitney U test.

normalized to the percentage of $\mathrm{LIN}^{-} \mathrm{DR}^{+} \mathrm{DC}$ precursors determined for each individual studied. As shown in Fig. 2A there was a significant difference in the relative proportions of MDC within the $\mathrm{LIN}^{-} \mathrm{DR}^{+} \mathrm{DC}$ population in patients vs. controls $(35.55 \pm 5.05 \%$ vs. $40.21 \pm 5.49 \%, \mathrm{p}=0.018)$, while the frequency of the PDC subset increased, but without reaching statistical significance $(36.19 \pm 6.81$ vs. $31.71 \pm 7.01, \mathrm{p}=0.078)$. When the data for MDC and PDC subsets for each subject were combined to determine the MDC:PDC ratio, patients exhibited a significantly lower mean value than normal controls $(1.03 \pm 0.29$ vs. $1.32 \pm 0.31, \mathrm{p}=0.010)$.

We next assessed the stimulatory capacity of pancreatic cancer patient-derived DC preparations ( $\mathrm{n}=16$; prior to either surgery or chemotherapeutic treatments), compared to those from normal donors $(n=12)$ in an allogeneic MLR. Although the yield of adherent cells in patients was close to control values (mean values respectively, 12.3 and 14.7\%) the stimulatory capacity of DC from patients was significantly lower than that of controls [SI, patients: median 3.41, range 2.32-4.89 vs. controls: median 4.84, range 3.1-7.6, $\mathrm{p}<0.001$ (Fig. 2B)].

Alteration of LAK activities in pancreatic carcinoma patients. Fig. 3 shows baseline cytotoxicity of freshly isolated PBL (NK) and IL-2-activated PBL (LAK) at effector-to-target cell 

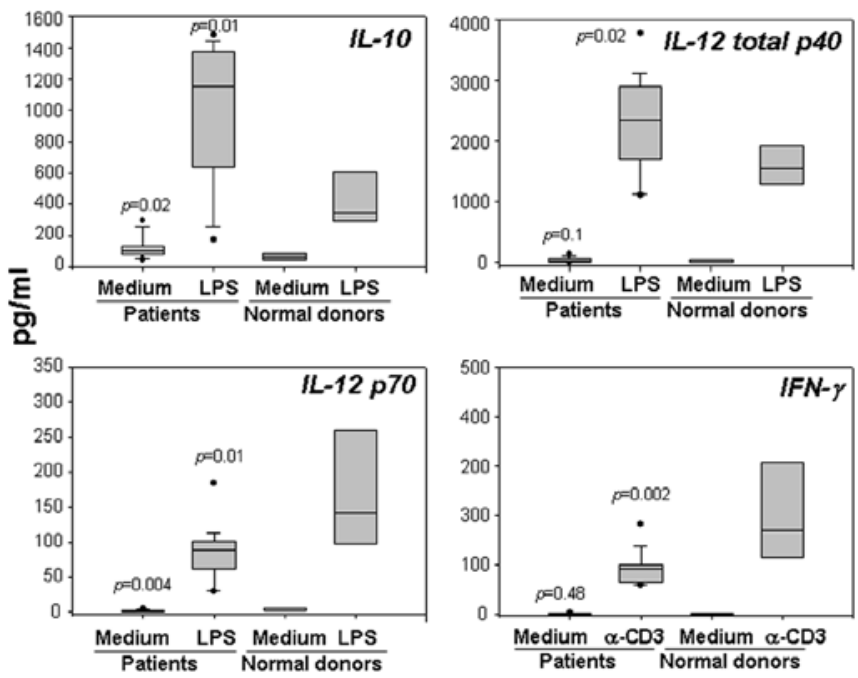

Figure 4. Concentration of IL-10, IL-12p40, IL-12p70 and IFN- $\gamma$ in supernatants of unstimulated and LPS-stimulated-PBMC or anti-CD3activated PBL from pancreatic carcinoma patients $(n=16)$ as compared to normal subjects $(n=16)$ measured by ELISA. The figure shows a box plot of cytokine levels. Horizontal lines indicate 10th, 25th, 50th (median), 75th, and 90th percentiles. Values above the 90th and below the 10th percentiles are plotted as points. $\mathrm{P}$ vs. controls are indicated.

ratios of 50:1 against K562 and Daudi target cells in pancreatic carcinoma patients and healthy controls. NK cytotoxicity assay of patients did not differ with that of control donors (median 32\%, range 23-37 vs. median 36\%, range 23-58, $\mathrm{p}=0.193)$, but exhibited a statistically significant decline in LAK activity (median $33.5 \%$, range $28-41$ vs. $58.5 \%$, range 45-67, $\mathrm{p}<0.001)$.

Elevated production of IL-10 and IL-12p40 and impaired production of IL-12p70 and IFN- $\gamma$ by stimulated-PBMC and $T$ cells from pancreatic carcinoma patients. As shown in Fig. 4, PBMC from patients produced higher levels of IL-10, either spontaneously or after stimulation with LPS, than that from the control group (basal conditions, $\mathrm{p}=0.023$; LPS, $\mathrm{p}=0.01$ ). The resting levels of IL-12 total $\mathrm{p} 40$ production by PBMC from tumor patients and controls did not differ $(\mathrm{p}=0.1)$, however, after LPS stimulation, the difference was statistically significant $(\mathrm{p}=0.02)$. It was noteworthy that, in the cancer patients, both PBMC production of IL-12p70 induced by LPS and PBL production of IFN- $\gamma$ induced in response to anti-CD3 exposure, were lower than in normal subjects (IL-12 p70, basal conditions: $\mathrm{p}=0.004$; LPS, $\mathrm{p}=0.01$; IFN $-\gamma$, basal conditions: $\mathrm{p}=0.48$; anti-CD3 stimulation, $\mathrm{p}=0.002$ ).

Immunological parameters and overall survival analysis. To define the clinical significance of the different immunological parameters in pancreatic carcinonoma patients, we analyzed the correlation between the immunological parameters evaluated and overall survival. No immunological parameters were significantly associated with patient survival except for IL-12p70 levels. As shown in Fig. 5, the Kaplan-Meier curve for overall survival of patients, subdivided on the basis of the median of LPS-induced IL-12p70 pg/ml/1x $10^{6}$ PBMC determined by specific ELISA and univariate analysis, showed that patients with low LPS-stimulated IL-12p70



Figure 5. Overall survival (analyzed by the Kaplan-Meier method) for patients

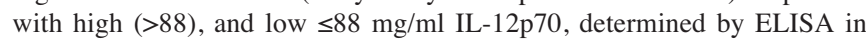
supernatant of LPS-stimulated PBMC from patients. The difference between the two groups is significant (log-rank test).

levels $(\leq 88 \mathrm{pg} / \mathrm{ml})$ had significantly shorter overall survival $(\mathrm{p}=0.007)$.

Effect of surgical treatment on the proportion of lymphocyte and DC subsets, cytokine production by PBMC and T cells, $D C$ allostimulatory activity and NK and LAK cytotoxic activity. Among the nine patients who underwent pancreatectomy (four radical and five palliative), only eight patients were evaluated, since one died of CAD three days after radical resection. Six patients were subsequently treated with chemotherapy for local advanced disease or the onset of metastasis. Post-operative analyses were performed approximately one month after surgery, when no patients had yet undergone any further anticancer treatment.

No significant difference in circulating lymphocyte numbers or frequency of the different subsets were detected between pre- and post-radical or palliative surgery (data not shown), with the exception of the percentage of the $\mathrm{T}$ lymphocyte subpopulation coexpressing CD3/CD95, which decreased significantly after radical resection (patients $n=3$, mean \pm SE pre: $36.7 \pm 3.4$, post: $13.3 \pm 2, p=0.006$ ) and decreased but only at the limit of statistical significance after palliative surgical treatment (patients $\mathrm{n}=5$, pre: $21.8 \pm 7.5$, post: $10.4 \pm 3.5, \mathrm{p}=0.05$ )

There was no significant change in MDC and PDC percentage or ratio one month after either radical or palliative surgery (data not shown, $\mathrm{p}>0.05$ ). However, postoperatively, the stimulatory capacity of DC was significantly higher in patients who had undergone radical resection than in those receiving palliative surgery (radical surgery, SI median, range: preoperative 2.56, 2.32-4.20 vs. postoperative 4.31, 3.98-5.70, $\mathrm{p}=0.001$; palliative surgery, SI median, range: preoperative $3.20,2.67-4.89$ vs. postoperative $3.45,2.63-4.56, \mathrm{p}=0.83$ ) (Fig. 6A and B). In addition, no significant difference in NK or LAK cytotoxicity was observed after surgery, in patients who had undergone radical resection nor in those who received palliative resection $(\mathrm{p}=1$ and $\mathrm{p}=0.098$, respectively, data not shown).

As shown in Table I, LPS-stimulated IL-10 production by PBMC was significantly reduced after radical tumor resection 
Table I. Effect of surgical treatment on spontaneous or stimulated cytokine production by PBMC and PBL.

\begin{tabular}{|c|c|c|c|c|c|c|}
\hline \multirow[b]{2}{*}{ Cytokine and culture conditions } & \multicolumn{2}{|c|}{ Radical surgery } & \multirow[b]{2}{*}{ P-value ${ }^{b}$} & \multicolumn{2}{|c|}{ Palliative surgery } & \multirow[b]{2}{*}{ P-value } \\
\hline & \multicolumn{2}{|c|}{$\mathrm{ng} / \mathrm{ml}$, median (range) } & & \multicolumn{2}{|c|}{$\mathrm{ng} / \mathrm{ml}$, median (range) } & \\
\hline \multicolumn{7}{|l|}{ IL-10 } \\
\hline Medium & $\begin{array}{c}101^{\mathrm{a}} \\
(94.5-118)\end{array}$ & $\begin{array}{c}97 \\
(87-97)\end{array}$ & NS & $\begin{array}{c}83 \\
(51.2-106)\end{array}$ & $\begin{array}{c}71 \\
(50-97)\end{array}$ & NS \\
\hline LPS & $\begin{array}{c}1231 \\
(996-1443)\end{array}$ & $\begin{array}{c}656 \\
(567-787)\end{array}$ & 0.04 & $\begin{array}{c}1362 \\
(531-1412)\end{array}$ & $\begin{array}{c}786 \\
(487-1342)\end{array}$ & NS \\
\hline \multicolumn{7}{|l|}{ IL- 12 total p40 } \\
\hline Medium & $\begin{array}{c}43^{\mathrm{a}} \\
(14-61)\end{array}$ & $\begin{array}{c}34 \\
(27-47)\end{array}$ & NS & $\begin{array}{c}38 \\
(23-56)\end{array}$ & $\begin{array}{c}42 \\
(10-71)\end{array}$ & NS \\
\hline LPS & $\begin{array}{c}2275 \\
(1231-3768)\end{array}$ & $\begin{array}{c}2656 \\
(987-2867)\end{array}$ & NS & $\begin{array}{c}2876 \\
(1362-3055)\end{array}$ & $\begin{array}{c}1978 \\
(1340-2989)\end{array}$ & NS \\
\hline \multicolumn{7}{|l|}{ IL-12 p70 } \\
\hline Medium & $\begin{array}{c}1.7^{\mathrm{a}} \\
(1.2-2)\end{array}$ & $\begin{array}{c}1.3 \\
(0.9-1.8)\end{array}$ & NS & $\begin{array}{c}1.2 \\
(0-3.1)\end{array}$ & $\begin{array}{c}1.5 \\
(0.9-2.3)\end{array}$ & NS \\
\hline LPS & $\begin{array}{c}85 \\
(76-100)\end{array}$ & $\begin{array}{c}135 \\
(127-136)\end{array}$ & 0.04 & $\begin{array}{c}62 \\
(34-105)\end{array}$ & $\begin{array}{c}123 \\
(35-156)\end{array}$ & 0.05 \\
\hline \multicolumn{7}{|l|}{$\mathrm{IFN}-\gamma$} \\
\hline Medium & $\begin{array}{c}0.6^{\mathrm{b}} \\
(0.4-0.8)\end{array}$ & $\begin{array}{c}0.5 \\
(0.3-0.7)\end{array}$ & NS & $\begin{array}{c}1.2 \\
(0-2.2)\end{array}$ & $\begin{array}{c}1.1 \\
(0.7-1.3)\end{array}$ & NS \\
\hline anti-CD3 & $\begin{array}{c}90 \\
(87-96)\end{array}$ & $\begin{array}{c}115 \\
(110-137)\end{array}$ & 0.03 & $\begin{array}{c}95 \\
(64-125)\end{array}$ & $\begin{array}{l}112,000 \\
(81-134)\end{array}$ & NS \\
\hline
\end{tabular}

${ }^{a}$ Spontaneous (medium) and LPS-induced cytokine releases by PBMC were evaluated by ELISA in cell free-supermatants. ${ }^{\mathrm{b}}$ Spontaneous (medium) and anti-CD3-induced IFN- $\gamma$ release by PBL was evaluated by ELISA in cell free-supernatants. P vs. preoperative values. NS, not statistically significant.

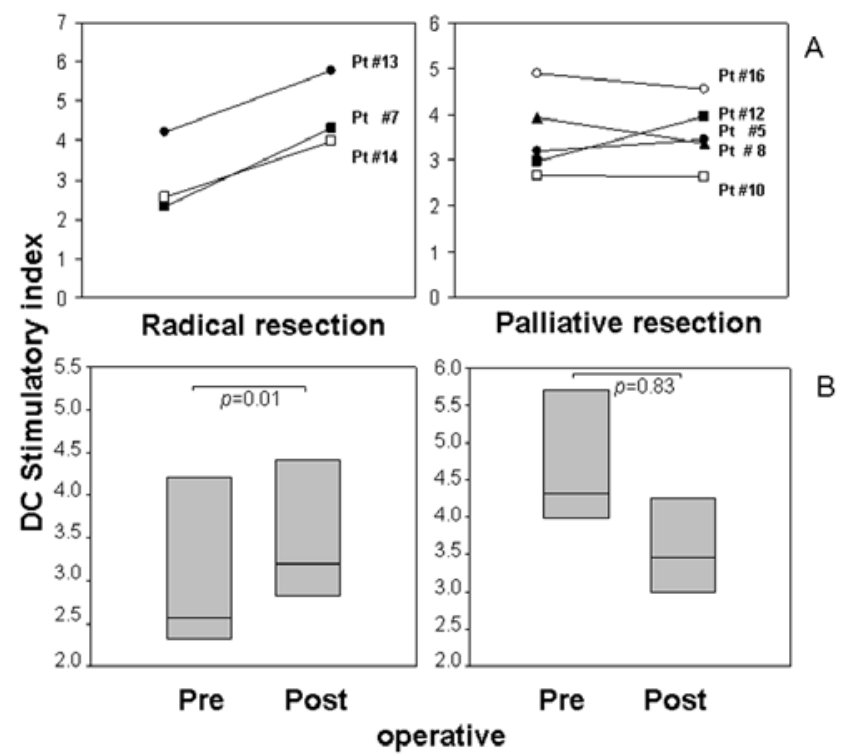

Figure 6. Post-operative changes in the stimulatory capacity of DC. (A) The stimulatory index (SI) of DC for each patient studied after pancreatectomy. (B) The SI of DC significantly increased after radical pancreatectomy $(\mathrm{p}=0.01)$. Data are expressed as the median (interquartile interval). Statistical significance was determined using the paired t-test. $(\mathrm{p}=0.04)$, but not after palliative resection. LPS-induced IL-12p70 release by PBMC increased significantly in patients after radical surgery $(\mathrm{p}=0.04)$, and remaine at the limit of statistical significance $(\mathrm{p}=0.05)$ in patients after palliative resection. Spontaneous and LPS-stimulated-IL-12 total p40 production remained unchanged. Concomitantly, in patients who had undergone radical surgery, the anti-CD3 stimulatedIFN- $\gamma$ production by PBL also increased $(\mathrm{p}=0.03)$.

Effects of combined chemotherapy on the proportion of $P B$ lymphocyte subsets. Of the sixteen patients, eleven underwent chemotherapy for locally-advanced or metastatic disease. Of the latter, five had not previously undergone surgery and were thus the only ones to enter the study: one patient completed four chemotherapy cycles (time 8), two received three cycles (time 6), one had two cycles (time 4) and the remaining one, who changed therapeutic protocol because of disease progression, only received a single cycle (time 2 ).

Lymphocyte counts indicated a decline in the absolute numbers in most subjects after the initial drug infusion (median 1.9 , range $0.9-2.2 \times 10^{6} / \mathrm{ml}$ vs. median 0.9 , range 0.7-1.8). After two chemotherapy cycles (time 4), the differences in average absolute numbers of lymphocytes 
Table II. Effect of chemotherapeutic treatment on the proportion of PB lymphocyte subsets.

\begin{tabular}{|c|c|c|c|c|c|}
\hline \multirow[b]{2}{*}{ Surface markers } & \multicolumn{5}{|c|}{ Time } \\
\hline & $0(\mathrm{n}=5)^{\mathrm{a}}$ & $2(n=5)$ & $4(n=4)$ & $6(n=3)$ & $8(n=1)$ \\
\hline CD3 & $72.75 \pm 4.3^{\mathrm{b}}$ & $74.5 \pm 5.3$ & $85 \pm 0.4$ & $73.66 \pm 4.5$ & 79 \\
\hline CD4 & $45.25 \pm 1.4$ & $51.25 \pm 5.2$ & $\begin{array}{c}61.75 \pm 5.6 \\
p=0.04\end{array}$ & $50.33 \pm 2.9$ & 45 \\
\hline $\mathrm{CD} 8$ & $22 \pm 4.5$ & $20 \pm 2.3$ & $21 \pm 2.4$ & $19.33 \pm 4.4$ & 35 \\
\hline CD56 & $18.25 \pm 2.9$ & $13.75 \pm 5.3$ & $12 \pm 4$ & $15 \pm 5$ & 14 \\
\hline CD19 & $9.37 \pm 2.7$ & $6.75 \pm 1.3$ & $5.25 \pm 1.25$ & $9 \pm 1$ & 5 \\
\hline CD3/CD95 & $26.75 \pm 9$ & $21.5 \pm 6.3$ & $14.5 \pm 2.1$ & $28.67 \pm 3.3$ & 24 \\
\hline
\end{tabular}

${ }^{a}$ Number of patients evaluated. ${ }^{b}$ Mean of positive cell percentage \pm SE. P vs. pretreatment values (time 0). Only differences statistically significant are presented.



Figure 7. Percentages of lymphocyte populations of each patient studied during the courses of chemotherapy. CD3, CD4, CD8, CD56, CD19 and CD3/CD95 expression in PBMC were quantified by flow cytometry.

were not statistically significant from those prior to treatment $(\mathrm{p}=0.23)$.

Individual changes in the different lymphocyte subset proportion after each course of therapy are shown in Fig. 7. Table II shows that, considering only those patients $(n=4)$ who completed the second cycle of chemotherapy, the mean percentage of $\mathrm{CD}^{+}$lymphocytes increased in patients after two chemotherapy cycles (time 4); however, it did not reach statistical significance $(\mathrm{p}=0.125)$. By contrast the $\mathrm{CD} 4^{+}$ subset was significantly enhanced at any of the times determinated.

Effect of the combined chemotherapy regimen on the proportion of DC subsets and DC allostimulatory activity. Individual changes in the MDC and PDC subsets and in the
MDC:PDC ratio after each course of therapy are shown in Fig. 8A. In all patients, the PDC frequency tended to decrease after the first and/or second course of chemotherapy (time 2, time 4). Considering only those patients $(n=4)$ who completed the second cycle of chemotherapy, there was on average a significant decrease in the relative proportions of PDC within the circulating $\mathrm{LIN}^{-} \mathrm{DR}^{+} \mathrm{DC}$ population after one (time 2 ) and after two cycles (time 4 ) of combined chemotherapy vs. before treatment (time 0$)($ mean \pm SE, time $2: 35.55 \pm 2.5 \%$ vs. time $0: 31.5 \pm 2.6 \%, \mathrm{p}=0.03$; time $4: 35.5 \pm 2.5$ vs. time 0 : $31.25 \pm 2.0 \%, \mathrm{p}=0.01$ ), while the frequency of the MDC subset remained unchanged ( $\mathrm{p}>0.05)$ (Fig. 8). Nevertheless, no significant difference in the MDC:PDC ratio was observed at any of the times.

The DC function was also assayed in patients before and after each chemotherapy course. As shown in Fig. 8B, in individual patients, modulation of the DC subsets was not necessarily accompanied by functional recovery. Considering only the four patients who completed two chemotherapy cycles, no significant change in allostimulatory activity of DC occurred during the treatment (SI median, range, time 2 vs. time 0: $2.90,2.77-3.78$ vs. $3.22,2.87-4.43, \mathrm{p}=0.11$; time 4 vs. time 0: $3.99,3-4.89$ vs. $3.22,2.87-4.43$, $\mathrm{p}=0.34$ ).

Effect of combined chemotherapy on NK and LAK cytotoxic activity. NK and LAK activity increased after chemotherapy in two out of five patients concomitantly with enhanced production of IL-12p70 and IFN- $\gamma$ (pt \#1 and pt \#6, Figs. 8 and 9). Considering only those patients $(n=4)$ who completed the second cycle of chemotherapy, no significant difference in the cytotoxic activity of NK was detected before vs. after chemotherapy. By contrast, LAK activity was increased after the first (time 2) and second (time 4) courses of chemotherapy ( $\mathrm{p}=0.041$ and $\mathrm{p}=0.05$, respectively) (Table III).

Effect of combined chemotherapy on cytokine production by $P B M C$. The spontaneous, LPS or anti-CD3 stimulated production of cytokines by PBMC and PBL cells, respectively, collected from patients after each course of chemotherapy was evaluated and compared with that measured at the time of diagnosis (time 0). As shown in Table IV, in general, no 



Time

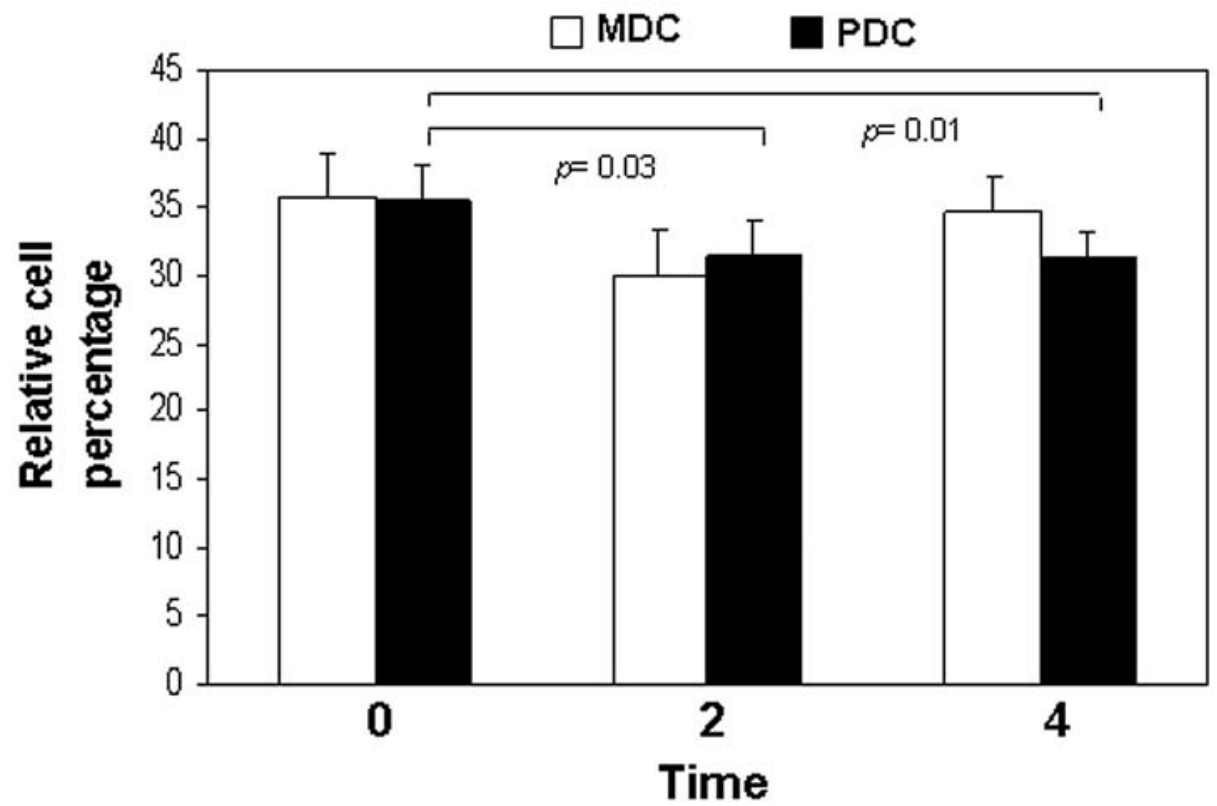

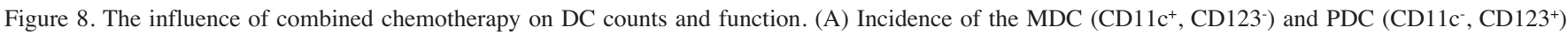
subsets (expressed as a percentage of LIN- HLA-DR+ PBMC), MDC:PDC ratio and DC allostimulation capacity (expressed as stimulation index) of each patient studied during the courses of chemotherapy. (B) Significant differences in PDC relative percentage induced by chemotherapy after the first (time 2) and the second (time 4) cycle.

significant change occurred in LPS induced IL-12 total p40 and $\mathrm{p} 70$, and IFN- $\gamma$ in comparison with pre-treatment values. By contrast, both spontaneous and LPS induced-IL-10 production significantly decreased at time 4 after combined chemotherapy ( $\mathrm{p}=0.018$ and $\mathrm{p}=0.047$, respectively). Howewer, the individual changes (Fig. 10), show that in three patients (\#1, \#2 and \#9) IL-10 levels produced by stimulated PBMC were reduced after two cycles, with concomitant enhanced production of IL-12p70 and IFN- $\gamma$ in two (\#1 and \#2) and in one (\#1) of them, respectively. 
Table III. Effect of chemotherapeutic treatment on NK and LAK cytotoxic activity.

\begin{tabular}{|c|c|c|c|c|c|}
\hline \multirow[b]{2}{*}{ Effector } & \multicolumn{5}{|c|}{$\%$ Specific cytotoxicity } \\
\hline & $0(\mathrm{n}=5)^{\mathrm{a}}$ & $2(n=5)$ & $4(n=4)$ & $6(n=3)$ & $8(n=1)$ \\
\hline NK & $37(29-41)^{b}$ & $37(26-40)$ & $41(23-52)$ & $35(21-50)$ & 48 \\
\hline LAK & $52(25-73)$ & $\begin{array}{c}63(29-79) \\
p=0.04\end{array}$ & $\begin{array}{c}57(33-88) \\
\mathrm{p}=0.05\end{array}$ & $72(32-75)$ & 68 \\
\hline
\end{tabular}

${ }^{\mathrm{a} N u m b e r}$ of patients evaluated. ${ }^{\mathrm{b}}$ Median (range). P vs. pretreatment values (time 0). Only differences statistically significant are presented.

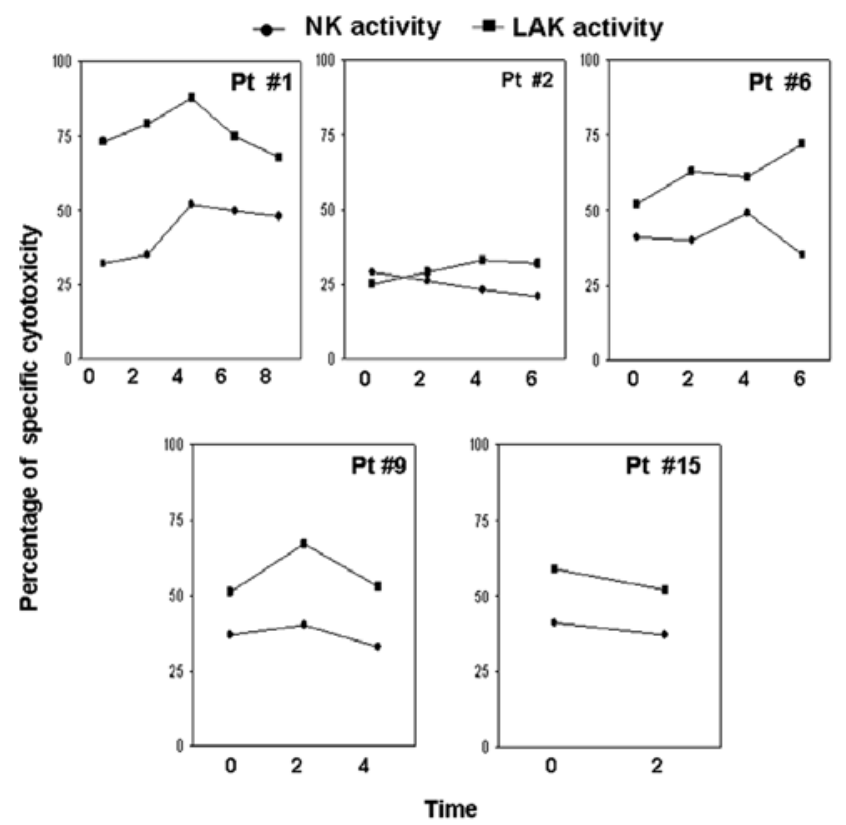

Figure 9. Effect of chemotherapy on NK and IL-2 induced LAK cytotoxic activity. The percentage of specific cytotoxicity against sensitive tumor targets for each patient studied during the courses of chemotherapy are shown.

\section{Discussion}

Accumulating data suggest that clinical outcome can be improved by combining standard cancer care with active immunotherapy (29-33). Although conventional chemotherapies are believed to suppress the immune response with a negative cumulative effect on the function of nonmalignant tissues and the immune system, previous studies have characterized their potential immunomodulating properties $(22,24,25,34-36)$.

In the present study we investigated the effect of surgical resection and a combined chemotherapy regimen, including cisplatin, gemcitabine and 5-FU, on a number of immunological parameters in pancreatic carcinoma patients; to the best of our knowledge we included more parameters than any prior study. We expected the follow-up to provide some new information that might be utilized in developing a future rational strategy for the integration of standard cancer treatment with immunotherapy in this deadly disease. To validate any possible deviations from the norm and the methods used we also included normal control subjects.
Lymphocytopenia, decreased $\mathrm{CD}^{+} \mathrm{T}$ cell frequency, and an increased proportion of $\mathrm{CD}^{+} / \mathrm{CD} 95^{+}$lymphocytes constitute the baseline immunologic abnormalities in the study population of pancreatic carcinoma patients. On the contrary, immunophenotype analyses showed that the B-cell and NK compartments remain intact.

From the immunotherapy perspective, it appears that a loss of $\mathrm{CD}^{+}$cytotoxic effector cells in association with very high proportions of $\mathrm{CD} 95^{+} \mathrm{T}$ cells that are potentially sensitive to apoptosis might foil attempts at strengthening antitumor responses in pancreatic carcinoma patients. The presence of spontaneous apoptosis-prone $\mathrm{T}$ cells in the peripheral circulation of cancer patients has been reported (37).

The malfunction of $\mathrm{T}$ lymphocytes may also be a secondary event occurring in these patients. Since $\mathrm{T}$ lymphocytes are activated by DC, functional abnormalities of these cells may be one of the main reasons for immune dysfunction. In agreement with previous studies (20), we found in general a defective allostimulatory function of DC generated ex vivo from pancreatic carcinoma patients. In different tumor types, numerous DC regulatory cytokines have been identified, which adversely affect the antitumor immune response; these include vascular endothelial growth factor (VEGF), IL-10, TGF- $\beta$ and IL-6. Some of these cytokines are produced by human tumor cells, while others are not only produced by the tumor cells but also induced systemically by tumor cell-derived products (38). In a previous study we identified an array of pancreatic carcinoma-derived cytokines that cooperatively affect DC activation in a manner consistent with ineffective antitumor immune responses (20). Moreover, similarly to our findings in that study (20), a relative decrease in the percentage of the $\mathrm{CD} 11 \mathrm{c}^{+}$MDC subsets in the peripheral circulation of pancreatic carcinoma patients compared to healthy individuals was also observed in the present study. MDC predominantly polarize towards the Th1 cell differentiation whereas the CD $123^{+}$PDC subset is capable of inducing Th2 cell differentiation and, in some instances, $\mathrm{T}$ cell hyporesponsiveness or anergy $(39,40)$. These results thus suggest that pancreatic cancer development, presumably through tumor-derived secreted cytokines, induces a systemic MDC/PDC imbalance in the host, with detrimental effects on antitumor immune responses. This is consistent with other studies in different tumor systems. For example, in squamous cell carcinomas of the head and neck, markedly lower numbers of circulating DC cells with myeloid characteristics (MDC) have been observed (41). Similar results have been reported for early 
Table IV. Effect of chemotherapeutic treatment on the spontanoeous, LPS- and anti-CD3-induced production of cytokines by PBMC and PBL.

\begin{tabular}{|c|c|c|c|c|c|}
\hline \multirow[b]{2}{*}{ Cytokines (pg/ml) } & \multicolumn{5}{|c|}{ Time } \\
\hline & $0(\mathrm{n}=5)^{\mathrm{a}}$ & $2(n=5)$ & $4(n=4)$ & $6(n=3)$ & $8(n=1)$ \\
\hline \multicolumn{6}{|l|}{ IL-10 } \\
\hline Medium & $104(67-258)^{\mathrm{a}}$ & $67(56-265)$ & $77(34-165)$ & $95(67-132)$ & 54 \\
\hline & $1101(273-1231)$ & $876(243-1145)$ & $\mathrm{p}=0.018$ & 495 (197-1165) & 512 \\
\hline LPS & & & $\begin{array}{c}239(118-367) \\
p=0.047\end{array}$ & & \\
\hline \multicolumn{6}{|l|}{ IL-12 total p40 } \\
\hline Medium & $32(10-77)$ & $30(21-65)$ & $27.5(13-65)$ & $32(15-67)$ & 29 \\
\hline LPS & 2207 (1101-2900) & $1990(1123-2432)$ & $1646(1234-1845)$ & 1965 (1895-1987) & 2312 \\
\hline \multicolumn{6}{|l|}{ IL-12p70 } \\
\hline Medium & $1.7(0-4.2)$ & $2.6(1-3.4)$ & $3.2(2.1-3.7)$ & $2.7(1.5-3.2)$ & 4.5 \\
\hline LPS & $90(30-102)$ & 87 (29-97) & $91(14-175)$ & $76(65-125)$ & 87 \\
\hline \multicolumn{6}{|l|}{ IFN- $\gamma$} \\
\hline Medium & $0.7(0-1)$ & $0.65(0.3-1)$ & $0.55(0.4-0.7)$ & $0.6(0.4-0.9)$ & 0.45 \\
\hline anti-CD3 & $72(61-95)$ & $67(57-87)$ & $77.5(43-105)$ & $91(65-98)$ & 87 \\
\hline
\end{tabular}

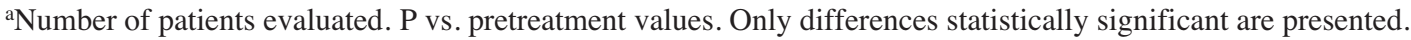

breast cancer, which is characterized by significant decreases in MDC (42).

NK cells are part of the innate immune system and are considered to be important players in the first line of defense against malignancies. IL-2-induced LAK cells, which are an expansion of MHC-unrestricted NK and killer T cells, have been clinically exploited in an effort to improve antitumor activity (43). However, no major benefit was reported for LAK protocols; moreover, systemic cytokine treatments utilized as an alternative approache in the hope of overcoming the limitations of original immunotherapies have not increased therapeutic efficiency, and caused severe toxic side effects (44).

As has been reported in patients with melanoma, breast carcinoma, bronchial carcinoma, and advanced gastrointestinal cancer (45-48), we found a depressed cytotoxic response of ex vivo IL-2 induced-LAK cells from pancreatic carcinoma patients. In contrast to that reported in patients with lung, esophageal, head and neck or breast cancer (49), we found ex vivo lytic NK cell function to be preserved in pancreatic carcinoma patients. The cytolytic activities of these effector cells are controlled by a variety of receptors which bind to major histocompatibility complex (MHC) class I molecules on target cells and mediate cell activation or inhibition (50). The loss of MHC class I molecules is a frequent mechanism in experimental and spontaneous tumors, whereby cells escape recognition and destruction by NK and CTL (51-53). Altered expression of MHC Class I has also been reported in pancreatic cancer cells (13).

Cytokines secreted by white blood cells play a key role in the regulation of innate and adaptive immune responses: cell-mediated immunity is preferentially activated by type 1 cytokines, including IL-2, IL-12, IL-15, and IFN- $\gamma$, whereas type 2 cytokines (IL-4, IL-5, IL-6, IL-13 and IL-10 in particular) have a suppressive action on cell-mediated immunity (54). Our analysis of cytokine levels released by LPS-activated PBMC and anti-CD3-stimulated T lymphocytes from pancreatic carcinoma patients revealed an elevated production of IL-10 and of total IL-12p40, and an impaired production of IL- 12 p70 and IFN- $\gamma$. IL-10 is a potent immunosuppressive cytokine, which inhibits $\mathrm{T}$ cell activation and Th1 cell differentiation. We and others have found elevated IL-10 serum levels in pancreatic carcinoma patients $(15,19,55)$.

Bioactive IL-12p70, composed of two disulphide-linked subunits designated p35 and p40, is a potent DC-derived cytokine capable of Th1/T cytotoxic skewing and activation, as the main stimulator of IFN- $\gamma$ production $(56,57)$. By contrast, the p40 subunit of IL-12, often made in excess, can dimerize to form a homodimer that can act as an IL-12p70 antagonist, by competing at their receptors on lymphocytes (58); it can also pair with p19 to form IL-23 (59). IL-23 has been shown to promote the up-regulation of the matrix metalloprotease MMP9, to increase angiogenesis and to reduce $\mathrm{CD}^{+} \mathrm{T}$ cell infiltration in the tumor environment (60). The role of IL-23 in pancreatic carcinoma is yet to be elucidated.

Given the role played by the immune system in tumor biology, our attention was also focused on the clinical application of our findings. We found that, among the immunological parameters, only IL-12p70 levels were correlated with survival. This is consistent with the crucial role played by this cytokine, which not only acts as a key regulator of cell-mediated immune responses through induction of Th1 differentiation and activation of DC $(56,57)$, but also induces 
IL-10, pg/ml
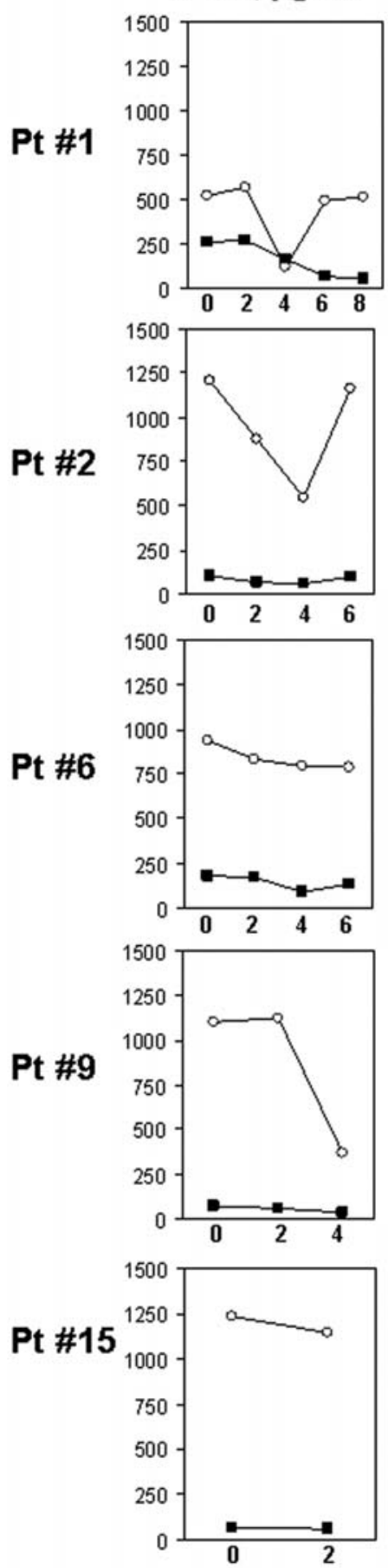

IL-12 p40, pg/mI IL-12 p70, pg/ml

IFN $\gamma, \mathrm{pg} / \mathrm{ml}$
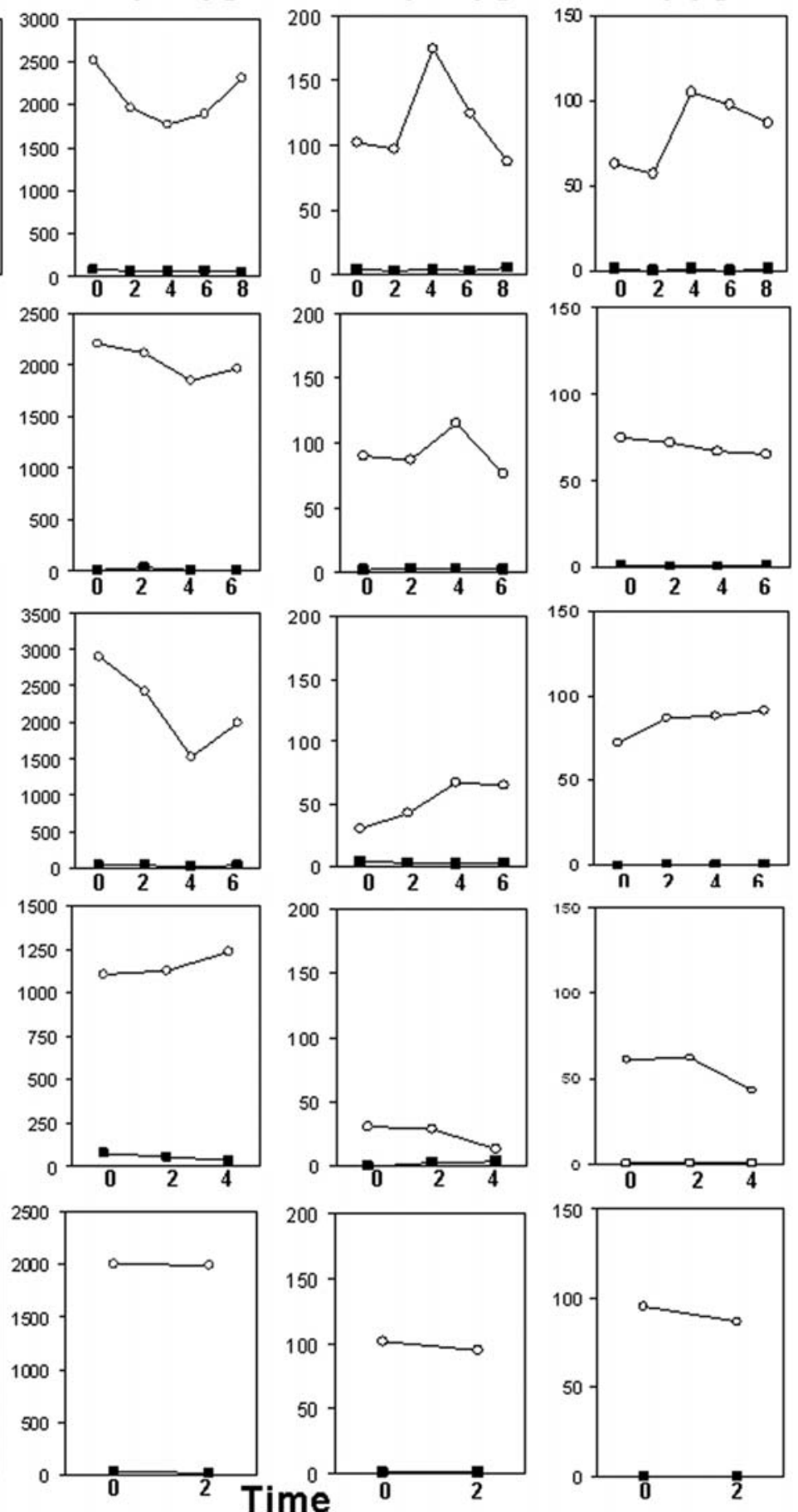

Figure 10. Effect of chemotherapy on spontaneous or induced cytokine production by PBMC from pancreatic carcinoma patients. At the time indicated, PBMC were untreated $(\square)$ or treated with LPS $(\bigcirc)$ to induce IL-10 and IL-12 production and PBL were untreated $(\square)$ or treated ( $\square$ ) with plate-bound antiCD3 monoclonal antibody to stimulate IFN- $\gamma$ release. IL-10, IL-12 total p40, IL-12p70 and IFN- $\gamma$ protein concentrations were determined in the supernatants with ELISA. Individual values are shown.

an antiangiogenic program mediated by IFN- $\gamma$-inducible genes and by lymphocyte-endothelial cell cross-talk (61).

Surgical resection of localized disease remains the only hope to cure pancreatic cancer. However, curative surgery is praticable only in a small group of patients; it is widely viewed as a complex procedure associated with considerable perioperative morbidity and mortality and the disease usually recurs.
The existence of a postoperative immunosuppression cascade triggered by surgical stress, consisting of increased immunosuppressive cytokines, decreased in helper and cytotoxic $\mathrm{T}$ cell populations and the development of suppressor $\mathrm{T}$ cells has been reported (62). However, one month after surgery, we found no significant changes in the number of circulating lymphocytes, with the exception of a marked decrease in frequency of the cell subset coexpressing CD3/ 
CD95. These data strongly suggest that pancreatic tumor cells may contribue to eliminating antitumor effector cells through a FasL/Fas interaction, as has been demonstrated in vitro (17).

The role of tumor cells in controlling the immune response in pancreatic cancer patients was further stressed by the finding that, after tumor resection, the production by stimulated PBMC and T cells respectively, of Th1 type cytokines (such as IL-12p70 and IFN- $\gamma$ was significantly enhanced; the capacity of DC was also improved, in agreement with a recent study (63). A tendency to increased NK and LAK cytotoxicity was observed, but it failed to reach statistical significance. As the majority of patients with pancreatic carcinoma have a poor prognosis after curative resection, these data show that early (one month) surgical removal of the tumor may exert some beneficial effects on the immune system that may be boosted by active immunotherapies aimed at activating antitumor immune responses.

Systemic chemotherapy still remains a standard of care for the treatment of patients with locally advanced and metastatic pancreatic cancer. Single therapy (5-FU or gemcitabine) to date has failed to demonstrate a clinically significant impact on the clinical course of pancreatic cancer (64). Studies have suggested that double/triple-drug combination regimens have superior antitumor effects compared with single agent alone (4,65-67). A combination of cisplatin, gemcitabine and infusional 5-FU was used in the treatment of locally advanced or metastatic pancreatic cancer patients enrolled in this study. This schedule was found in a phase II study to be well tolerated and active against pancreatic cancer (27).

The present study showed that, after two cycles of the combined treatment, the percentage of circulating $\mathrm{CD}^{+}{ }^{+}$subset increased. These cells were shown not to belong to the CD4 ${ }^{+}$ $\mathrm{CD} 25^{+} / \mathrm{Foxp}^{+} \mathrm{T}$ regulatory cell subset, since we have found that these suppressor cells actually decrease (unpublished data). CD4 ${ }^{+}$Th cells, and in particular IFN- $\gamma$-secreting Th1 cells, which commitmently rely on the local production of bioactive IL-12, have been shown to fulfill a critical function in the mounting of a cancer-specific response (68). We found that, at least in some patients, IL-12p70 and IFN- $\gamma$ production by stimulated cells was enhanced after the second cycle. An increased percentage of $\mathrm{CD}^{+}$has also been found in subjects with pancreatic carcinoma after treatment with gemcitabine as single agent (69).

Of note, we also observed a measurable decrease in PDC cells in pancreatic carcinoma patients after the first and/or second course of chemotherapy. Even if no significant DC functional recovery was concomitantly found, probably due to the limited series, it appears clear that the combination of cisplatin, gemcitabine and FU-5 can be administered to patients with pancreatic cancer without relevant loss of DC precursors and function.

Human tumor antigens recognized by $\mathrm{T}$ cells have recently been identified in various cancers, including pancreatic cancer (70). The direct cytolytic effect of cytotoxic drugs, such as cisplatin, gemcitabine and 5-FU, can enhance antigen presentation by inducing tumor cell apoptosis. No studies on the effect on DC function of the three-drug combination used in this study were available. However, it has been demonstrated that in vivo gemcitabine, used as single agent, by inducing apoptosis, may increase the cross-presentation of tumor antigens to CTL by intratumoral DC and may enhance the effectiveness of the DC-based vaccine by augmenting the effectiveness of immune stimulation through in vivo CD40 ligation and by reducing myeloid suppressor cells (69).

The three-drug association used here appears not significantly influence the killing ability of NK, that therefore retain their innate potential to recognize tumor cells. By contrast, at certain time points in the treatment cycles (in particular after two or three cycles), the capacity to generate ex vivo functionally-active LAK cells from the PBL of the patients was significantly increased vs. that prior to treatment. The characterization of the biological function of NK cells, in particular in human antitumor immunosurveillance, is still incomplete due to the complexity of activating and inhibiting receptor sets capable of recognising the corresponding ligands on tumor cells. However, epidemiologic surveys have shown that the extent of NK cell activity in the peripheral blood is associated with cancer risk (71). Moreover, tumors are not uniform in their sensitivity to immune effector cell lysis, and the resistance to cytotoxic activity of immune effector cells plays a key role in therapy failures in many tumors. LAK cells, originally used in antitumor cellular immunotherapy because of their ability to recognize and kill tumor cells with little consideration for immune specificity, have not provided the positive results that were hoped for regarding their clinical effectiveness. The results of our study suggest an improved form of this therapy in combination with antitumor drugs.

Several lines of evidence suggest that 5-FU and cisplatin can induce killer cell activities having an antitumor effect in cancer patients (72-76). The activity might also occur on the part of tumor cells since cisplatinum, gemcitabine and 5-FU have been shown to increase the susceptibility of tumor cells to immune effector cells (NK cells or CD8 ${ }^{+}$CTL) (72,77-80). All these mechanisms offer numerous opportunities for potential therapeutic synergy with tumor vaccines.

Recently it has been suggested that chemotherapy might improve the immune function by reducing the levels of immunosuppressive cytokines produced by cancer cells (81). In comparison with the pre-treatment conditions, we found no significant changes in LPS-induced IL-12 total p40 and p70 by PBMC, nor in anti-CD3-induced IFN- $\gamma$ release by T cells. The small number of patients and the marked inter-individual variability in the parameters measured, might contribute to the lack of statistical significance. Overall, a significant decrease in both spontaneous and LPS-induced IL-10 production occurred at time point 4 after combined chemotherapy. At the individual level, in two patients this reduction paralled a significantly enhanced production of IL-12p70 and IFN- $\gamma$. These data suggest that triple therapy with cisplatin, gemcitabine and 5-FU does not inhibit Th1-cell activation nor their ability to produce Th1 cytokines, but may depress Th2 cell activation and their ability to produce Th2 cytokines, such as IL-10.

Data indicating that gemcitabine may inhibit Th2- and specifically augment Th1-type immune responses in cancer patients has recently been reported (69). Since the current standards of treatment are ineffective for many patients with advanced pancreatic cancer, the potential benefits of a 
combination with immunotherapy appears to be a promising approach that should be further examined.

Overall, the findings from this pilot study show that neither specialist surgical resection nor cisplatin + gemcitabine $+5-\mathrm{FU}$ combined chemotherapy are detrimental to cellular antitumor immunity, and may even positively influence the immune system. This suggests that it may in future be possible to rationally combine active immunotherapy with these therapeutic modalities, capitalizing on an additive or even a synergistic activity. We found that, especially chemotherapeutic treatment at certain points, by altering the immunologic milieu in which the antitumor immune response develops, can potentiate the vaccine-induced immune response. It is unclear whether the drug combination used here is unique in its immunomodulatory properties or whether the effect is shared by the individual drug when used as single agent. However, the immunological changes observed indicate specific and precisely-timed windows of opportunity for introducing immunotherapy with the possibility of improving cure and survival rates in a highly lethal disease. Timing thus appears to be crucial: surgery and/or chemotherapy closely followed by immunotherapy seems to be the most appropriate modality in pancreatic carcinoma.

However, the interaction between therapies is clearly a finely balanced one. Careful preclinical studies are essential for designing the most informative clinical trials, ensuring that tumor vaccines are effectively integrated with standard cancer care to improve clinical outcome.

\section{Acknowledgements}

Supported by grants from the Piedmont Regional Government (Regione Piemonte) and 'Compagnia di San Paolo' Foundation (Turin, Italy) to GB.

\section{References}

1. Parkin DM, Bray FI and Devesa SS: Cancer burden in the year 2000. The global picture. Eur J Cancer 37: S4-S66, 2001.

2. Kuvshinoff BW and Bryer MP: Treatment of resectable and locally advanced pancreatic cancer. Cancer Control 7: 428-436, 2000.

3. Cohen SJ, Pinover WH, Watson JC and Meropol NJ: Pancreatic cancer. Curr Treat Options Oncol 1: 375-386, 2000.

4. Philip PA: Gemcitabine and platinum combinations in pancreatic cancer. Cancer 95: 908-911, 2002.

5. Oettle H and Riess H: Gemcitabine in combination with 5fluorouracil with or without folinic acid in the treatment of pancreatic cancer. Cancer 95: 912-922, 2002.

6. Ducreux M, Boige V and Malka D: Treatment of advanced pancreatic cancer. Semin Oncol 34: S25-S30, 2007.

7. Huang P, Chubb S, Hertel LW, Grindey GB and Plunkett W: Action of 2',2'-difluorodeoxycytidine on DNA synthesis. Cancer Res 51: 6110-6117, 1991

8. Nowak AK, Robinson BW and Lake RA: Gemcitabine exerts a selective effect on the humoral immune response:implications for combination chemo-immunotherapy. Cancer Res 62 2353-2358, 2002.

9. Nio Y, Hirahara N, Minari Y, Iguchi C, Yamasawa K, Toga T and Tamura K: Induction of tumor-specific antitumor immunity after chemotherapy with cisplatin in mice bearing MOPC-104E plasmacytoma by modulation of MHC expression on tumor surface. Anticancer Res 20: 3293-3299, 2000.

10. Merritt RE, Mahtabifard A, Yamada RE, Crystal RG and Korst RJ: Cisplatin augments cytotoxic T-lymphocyte-mediated antitumor immunity in poorly immunogenic murine lung cancer. J Thorac Cardiovasc Surg 126: 1609-1617, 2003.
11. Okamoto M, Ohe G, Oshikawa T, Nishikawa H, Furuichi S, Yoshida $\mathrm{H}$ and Sato M: Induction of cytokines and killer cell activities by cisplatin and 5-fluorouracil in head and neck cancer patients. Anticancer Drugs 11: 165-173, 2000.

12. Goldrosen MH, Dasmahapatra K, Jenkins D, Howell JH, Arbuck SG, Moore MC and Douglass HO Jr: Microplate leucocyte adherence inhibition (LAI) assay in pancreatic cancer: detection of specific antitumor immunity with patients' peripheral blood cells and serum. Cancer 47: 1614-1619, 1981.

13. Scupoli MT, Sartoris S, Tosi G, Ennas MG, Nicolis M, Cestari T, Zamboni G, Martignoni G, Lemoine NR, Scarpa A and Accolla RS: Expression of MHC class I and class II antigens in pancreatic adenocarcinomas. Tissue Antigens 48: 301-311, 1996.

14. Marincola FM, Jaffee EM, Hicklin DJ and Ferrone S: Escape of human solid tumors from T-cell recognition: molecular mechanisms and functional significance. Adv Immunol 74: $181-273,2000$

15. von Bernstorff W, Voss M, Freichel S, Schmid A, Vogel I, Jöhnk C, Henne-Bruns D, Kremer B and Kalthoff H: Systemic and local immunosuppression in pancreatic cancer patients. Clin Cancer Res 7: 925s-932s, 2001.

16. Igney FH and Krammer PH: Tumor counterattack: fact or fiction? Cancer Immunol Immunother 54: 1127-1136, 2005.

17. Bellone G, Smirne C, Carbone A, Mareschi K, Dughera L, Farina EC, Alabiso O, Valente G, Emanuelli G and Rodeck U: Production and pro-apoptotic activity of soluble CD95 ligand in pancreatic carcinoma. Clin Cancer Res 6: 2448-2455, 2000 .

18. Bellone G, Smirne C, Mauri FA, Tonel E, Carbone A, Buffolino A, Dughera L, Robecchi A, Pirisi M and Emanuelli G: Cytokine expression profile in human pancreatic carcinoma cells and in surgical specimens: implications for survival. Cancer Immunol Immunother 55: 684-698, 2006.

19. Bellone G, Turletti A, Artusio E, Mareschi K, Carbone A, Tibaudi D, Ribecchi A, Emanuelli G and Rodeck U: Tumorassociated transforming growth factor-beta and interleukin-10 contribute to a systemic Th2 immune phenotype in pancreatic carcinoma patients. Am J Pathol 155: 537-547, 1999.

20. Bellone G, Carbone A, Smirne C, Scirelli T, Buffolino A, Novarino A, Stacchini A, Bertetto O, Palestro G, Sorio C, Scarpa A, Emanuelli G and Rodeck U: Cooperative induction of a tolerogenic dendritic cell phenotype by cytokines secreted by pancreatic carcinoma cells. J Immunol 177: 3448-3460, 2006.

21. Kawakami Y, Okada T and Akada M: Development of immunotherapy for pancreatic cancer. Pancreas 28: 320-325, 2004.

22. Lake RA and Robinson BW: Immunotherapy and chemotherapy - a practical partnership. Nat Rev Cancer 5: 397-405, 2005

23. Schultz ES and Schuler G: Malignant melanoma. Diagnosis and therapy. HNO 53: 928-939, 2005.

24. van der Most RG, Currie A, Robinson and Lake RA: Cranking the immunologic engine with chemotherapy: using context to drive tumor antigen cross-presentation towards useful antitumor immunity. Cancer Res 66: 601-604, 2006.

25. Nowak AK, Lake RA and Robinson BW: Combined chemoimmunotherapy of solid tumours: improving vaccines? Adv Drug Deliv Rev 58: 975-990, 2006.

26. Sobin LH and Wittekind CL: International Union Against Cancer (UICC). TNM classification of malignant tumors. John Wiley \& Sons, Inc, New York, 2002.

27. Novarino A, Chiappino I, Bertelli GF, Heouaine A, Ritorto G, Addeo A, Bellone G, Merlano M and Bertetto O: Phase II study of cisplatin, gemcitabine and 5-fluorouracil in advanced pancreatic cancer. Ann Oncol 15: 474-477, 2004.

28. Robinson SP, Patterson S, English N, Davies D, Knight SC and Reid CD: Human peripheral blood contains two distinct lineages of dendritic cells. Eur J Immunol 29: 2769-2778, 1999.

29. Shin JY, Lee SK, Kang CD, Chung JS, Lee EY, Seo SY, Lee SY, Baek SY, Kim BS, Kim JB and Yoon S: Antitumor effect of intratumoral administration of dendritic cell combination with vincristine chemotherapy in a murine fibrosarcoma model. Histol Histopathol 18: 435-447, 2003.

30. Yu B, Kusmartsev S, Cheng F, Paolini M, Nefedova Y, Sotomayor E and Gabrilovich D: Effective combination of chemotherapy and dendritic cell administration for the treatment of advanced-stage experimental breast cancer. Clin Cancer Res 9: 285-294, 2003. 
31. Correale P, Cusi MG, Tsang KY, Del Vecchio MT, Marsili S, Placa ML, Intrivici C, Aquino A, Micheli L, Nencini C, Ferrari F, Giorgi G, Bonmassar E and Francini G: Chemo-immunotherapy of metastatic colorectal carcinoma with gemcitabine plus FOLFOX 4 followed by subcutaneous granulocyte macrophage colony-stimulating factor and interleukin-2 induces strong immunologic and antitumor activity in metastatic colon cancer patients. J Clin Oncol 23: 8950-8958, 2005.

32. Ko HJ, Kim YJ, Kim YS Chang WS, Ko SY, Chang SY, Sakaguchi S and Kang CY: A combination of chemoimmunotherapies can efficiently break self-tolerance and induce antitumor immunity in a tolerogenic murine tumor model. Cancer Res 67: $7477-7486,2007$

33. Audia S, Nicolas A, Cathelin D, Larmonier N, Ferrand C, Foucher P, Fanton A, Bergoin E, Maynadie M, Arnould L, Bateman A, Lorcerie B, Solary E, Chauffert B and Bonnotte B: Increase of $\mathrm{CD}^{+} \mathrm{CD} 25^{+}$regulatory $\mathrm{T}$ cells in the peripheral blood of patients with metastatic carcinoma: a Phase I clinical trial using cyclophosphamide and immunotherapy to eliminate $\mathrm{CD} 4{ }^{+} \mathrm{CD} 25^{+} \mathrm{T}$ lymphocytes. Clin Exp Immunol 150: 523-530, 2007

34. Micheau O, Solary E, Hammann A, Martin F and DimancheBoitrel MT: Sensitization of cancer cells treated with cytotoxic drugs to fas-mediated cytotoxicity. J Natl Cancer Inst 89: 783-789, 1997.

35. Emens LA: Chemotherapy and tumor immunity: an unexpected collaboration. Front Biosci 13: 249-257, 2008

36. Ménard C, Martin F, Apetoh L, Bouyer F and Ghiringhelli F: Cancer chemotherapy: not only a direct cytotoxic effect, but also an adjuvant for antitumor immunity. Cancer Immunol Immunother 57: 1579-1587, 2008

37. Whiteside TL: Apoptosis of immune cells in the tumor microenvironment and peripheral circulation of patients with cancer: implications for immunotherapy. Vaccine 20: A46-A51, 2002.

38. Kusmartsev S and Gabrilovich DI: Effect of tumor-derived cytokines and growth factors on differentiation and immune suppressive features of myeloid cells in cancer. Cancer Metastasis Rev 25: 323-331, 2006

39. Rissoan MC, Soumelis V, Kadowaki N, Grouard G, Briere F, de Waal Malefyt R and Liu YJ: Reciprocal control of T helper cell and dendritic cell differentiation. Science 283: 1183-1186, 1999.

40. Kuwana M: Induction of anergic and regulatory $\mathrm{T}$ cells by plasmacytoid dendritic cells and other dendritic cell subsets, Hum Immunol 63: 1156-1163, 2002.

41. Almand B, Resser JR, Lindman B, Nadaf S, Clark JI, Kwon ED Carbone DP and Gabrilovich DI: Clinical significance of defective dendritic cell differentiation in cancer. Clin Cancer Res 6: $1755-1766,2000$

42. Della Bella S, Gennaro M, Vaccai M, Ferraris C, Nicola S, Riva A, Clerici M, Greco M and Villa ML: Altered maturation of peripheral blood dendritic cells in patients with breast cancer. Br J Cancer 89: 1463-1472, 2003.

43. Atzpodien $\mathrm{J}$ and Kirchner H: Cancer, cytokines, and cytotoxic cells: interleukin-2 in the immunotherapy of human neoplasms. Klin Wochenschr 68: 1-11, 1990.

44. Kammula US and Marincola FM: Cancer immunotherapy: is there real progress at last? BioDrugs 11: 249-260, 1999.

45. Balch CM, Itoh $\mathrm{K}$ and Tilden AB: Cellular immune defects in patients with melanoma involving interleukin-2-activated lymphocyte cytotoxicity and a serum suppressor factor. Surgery 98: 151-157, 1985

46. Monson JR, Ramsden CW, Giles GR, Brennan TG and Guillou PJ: Lymphokine activated killer (LAK) cells in patients with gastrointestinal cancer. Gut 28: 1420-1425, 1987.

47. Baxevanis CN, Reclos GJ, Gritzapis AD, Dedousis GV, Missitzis I and Papamichail M: Elevated prostaglandin E2 production by monocytes is responsible for the depressed levels of natural killer and lymphokine-activated killer cell function in patients with breast cancer. Cancer 72: 491-501, 1993.

48. McCulloch PG and MacIntyre A: Effects of surgery on the generation of lymphokine-activated killer cells in patients with breast cancer. Br J Surg 80: 1005-1007, 1993.

49. Bauernhofer T, Kuss I, Henderson B, Baum AS and Whiteside TL: Preferential apoptosis of CD56dim natural killer cell subset in patients with cancer. Eur J Immunol 33: 119-124, 2003

50. Biassoni R, Cantoni C, Pende D, Sivori S, Parolini S, Vitale M, Bottino C and Moretta A: Human natural killer cell receptors and co-receptors. Immunol Rev 181: 203-214, 2001.
51. Garrido F, Cabrera T, Concha A, Glew S, Ruiz-Cabello F and Stern PL: Natural history of HLA expression during tumor development. Immunol Today 14: 491-493, 1993.

52. Hicklin DJ, Marincola FM and Ferrone S: HLA class I antigen downregulation in human cancers: $\mathrm{T}$ cell immunotherapy revives an old story. Mol Med Today 5: 178-186, 1999.

53. Garrido F, Ruiz-Cabello F, Cabrera T, Pérez-Villar JJ, López-Botet M, Duggan-Keen M and Stern PL: Implications for immunosurveillance of altered class I phenotypes in humans tumors. Immunol Today 18: 89-95, 1997

54. Romagnani S: Human TH1 and TH2 subsets: doubt no more. Immunol Today 12: 256-257, 1991.

55. Ebrahimi B, Tucker SL, Li D, Abbruzzese JL and Kurzrock R: Cytokines in pancreatic carcinoma: correlation with phenotypic characteristics and prognosis. Cancer 101: 2727-2736, 2004.

56. Trinchieri G: Interleukin-12: a proinflammatory cytokine with immunoregulatory functions that bridge innate resistance and antigen-specific adaptive immunity. Annu Rev Immunol 13: 251-276, 1995

57. Hilkens CM, Kalinski P, de Boer M and Kapsenberg ML: Human dendritic cells require exogenous interleukin-12-inducing factors to direct the development of naive T-helper cells toward the Th1 phenotype. Blood 90: 1920-1926, 1997.

58. Germann T, Rüde E, Mattner F and Gately MK: The IL-12 p40 homodimer as a specific antagonist of the IL-12 heterodimer. Immunol Today 16: 500-501, 1995.

59. Trinchieri G: Interleukin-12 and the regulation of innate resistance and adaptive immunity. Nat Rev Immunol 3: 133-146, 2003.

60. Kastelein RA, Hunter CA and Cua DJ: Discovery and biology of IL-23 and IL-27: Related but functionally distinct regulators of inflammation. Annu Rev Immunol 25: 221-242, 2007.

61. Duda DG, Sunamura M, Lozonschi L, Kodama T, Egawa S, Matsumoto G, Shimamura H, Shibuya K, Takeda K and Matsuno S: Direct in vitro evidence and in vivo analysis of the antiangiogenesis effects of interleukin 12. Cancer Res 60: $1111-1116,2000$

62. Shakhar G and Ben-Eliyahu S: Potential prophylactic measures against postoperative immunosuppression: could they reduce recurrence rates in oncological patients? Ann Surg Oncol 10: 972-992, 2003

63. Takahashi K, Toyokawa H, Takai S, Satoi S, Yanagimoto $H$, Terakawa N, Araki H, Kwon AH and Kamiyama Y: Surgical influence of pancreatectomy on the function and count of circulating dendritic cells in patients with pancreatic cancer. Cancer Immunol Immunother 55: 775-784, 2006.

64. Abbruzzese JL: Past and present treatment of pancreatic adenocarcinoma: chemotherapy as a standard treatment modality. Semin Oncol 29: 2-8, 2002.

65. Philip PA, Zalupski MM, Vaitkevicius VK, Arlauskas P, Chaplen R, Heilbrun LK, Adsay V, Weaver D and Shields AF: Phase II study of gemcitabine and cisplatin in the treatment of patients with advanced pancreatic carcinoma. Cancer 92: 569-577, 2001.

66. Heinemann V, Wilke H, Mergenthaler HG, Clemens M, König H, Illiger HJ, Arning M, Schalhorn A, Possinger K and Fink U: Gemcitabine and cisplatin in the treatment of advanced or metastatic pancreatic cancer. Ann Oncol 11: 1399-1403, 2000.

67. Colucci G, Giuliani F, Gebbia V, Biglietto M, Rabitti P, Uomo G, Cigolari S, Testa A, Maiello E and Lopez M: Gemcitabine alone or with cisplatin for the treatment of patients with locally advanced and/or metastatic pancreatic carcinoma: A prospective, randomized phase III study of the Gruppo Oncologia dell'Italia Meridionale. Cancer 94: 902-910, 2002.

68. Marzo AL, Kinnear BF, Lake RA, Frelinger JJ, Collins EJ, Robinson BW and Scott B: Tumor-specific CD4 ${ }^{+} \mathrm{T}$ cells have a major 'post-licensing' role in CTL mediated anti-tumor immunity. J Immunol 165: 6047-6055, 2000.

69. Plate JM, Plate AE, Shott S, Bograd S and Harris JE: Effect of gemcitabine on immune cells in subjects with adenocarcinoma of the pancreas. Cancer Immunol Immunother 54: 915-925, 2005.

70. Boon T and van der Bruggen P: Human tumor antigens recognized by T lymphocytes. J Exp Med 183: 725-729, 1996.

71. Imai K, Matsuyama S, Miyake S, Suga K and Nakachi K: Natural cytotoxic activity of peripheral-blood lymphocytes and cancer incidence: an 11-year follow-up study of a general population. Lancet 356: 1795-1799, 2000.

72. Yang S and Haluska FG: Treatment of melanoma with 5fluorouracil or dacarbazine in vitro sensitizes cells to antigenspecific CTL lysis through perforin/granzyme- and Fasmediated pathways. J Immunol 172: 4599-4608, 2004. 
73. Collins JL and Kao MS: The anticancer drug, cisplatin, increases the naturally occurring cell mediated lysis of tumor cells. Cancer Immunol Immunother 29: 17-22, 1989.

74. Yamaue H, Tanimura H, Noguchi K, Iwahashi M, Tsunoda T, Tani M, Tamai M, Hotta T, Mizobata S and Arii K: Cisplatin treatment renders tumor cells more susceptible to attack by lymphokine-activated killer cells. J Clin Lab Immunol 35 : 165-170, 1991

75. Mizutani Y, Bonavida B, Nio Y and Yoshida O: Enhanced susceptibility of cis-diamminedichloroplatinum-treated K562 cells to lysis by peripheral blood lymphocytes and lymphokine activated killer cells. Cancer 71: 1313-1321, 1993.

76. Matsuzaki I, Suzuki H, Kitamura M, Minamiya Y, Kawai H and Ogawa J: Cisplatin induces fas expression in esophageal cancer cell lines and enhanced cytotoxicity in combination with LAK cells. Oncology 59: 336-343, 2000.

77. Nowak AK, Lake RA, Marzo AL, Scott B, Heath WR, Collins EJ, Frelinger JA and Robinson BW: Induction of tumor cell apoptosis in vivo increases tumor antigen cross-presentation, cross-priming rather than cross-tolerizing host tumor-specific CD8 T cells. J Immunol 170: 4905-4913, 2003.
78. Huang GC, Liu SY, Lin MH, Kuo YY and Liu YC: The synergistic cytotoxicity of cisplatin and taxol in killing oral squamous cell carcinoma. Jpn J Clin Oncol 34: 499-504, 2004.

79. Chhipa RR and Bhat MK: Bystander killing of breast cancer MCF-7 cells by MDA-MB-231 cells exposed to 5-fluorouracil is mediated via Fas. J Cell Biochem 101: 68-79, 2007.

80. Correale P, Del Vecchio MT, La Placa M, Montagnani F, Di Genova G, Savellini GG, Terrosi C, Mannucci S, Giorgi G, Francini $\mathrm{G}$ and Cusi MG: Chemotherapeutic drugs may be used to enhance the killing efficacy of human tumor antigen peptidespecific CTLs. J Immunother 31: 132-147, 2008.

81. Yanagimoto H, Takai S, Satoi S, Toyokawa H, Takahashi K, Terakawa N, Kwon AH and Kamiyama Y: Impaired function of circulating dendritic cells in patients with pancreatic cancer. Clin Immunol 114: 52-60, 2005. 